\title{
Pendidikan Life Skills di Pesantren
}

\author{
Suharmoko \\ Sekolah Tinggi Agama Islam Negeri (STAIN) Sorong Papua Barat \\ moking_mortosugito@gmail.com
}

\begin{abstract}
This study aims to know life skill implementation at Islamic Boarding School Darul Falah Be-Songo Ngaliyan Semarang. This study is a library research by examining various literature or relevant research as a source of data. The results of the study show that Islamic Boarding School Darul Falah Be-Songo Ngaliyan Semarang has organized activities that have life s skills. These skills include vocational skills and academic skills. Vocational skills here in the form of cooking skills, embroidery, make-up and other types of crafts. In addition, in it also taught how the students can speak well, both in expressing opinions and in speeches and other skills that become the main attraction for the surrounding community. The benefits, can improve the quality of thinking, quality of heart, and physical quality of students. In addition, for the environment in which the students are located or for the community can improve the life of advanced and civil. Furthermore, in the implementation carried out into three stages, namely the stage of planning, implementation phase, and evaluation phase that all done aimed for this Education in accordance with the suggestions have made.
\end{abstract}

Keywords: Education, Islamic Boarding School, Life Skills, Vocational Skills and Academic Skills. 


\section{Pendahuluan}

Pendidikan berwawasan life skills kini menjadi terobosan baru di dunia pesantren. Pengaplikasian pendidikan berbasis life skills di pesantren mampu melahirkan output santri yang berkualitas dan kompetitif. Selain itu pendidikan ini didesain untuk membekali santri dalam menghadapi dan memecahkan problema hidup dan kehidupan. Mencetak santri berkualitas di sini menjadi tanggung jawab lembaga pendidikan. Sedangkan lembaga pendidikan tersebut harus menjadi lembaga pendidikan yang berkualitas. Ada tiga hal yang harus dilalui oleh sebuah lembaga pendidikan untuk mempersembahkan pendidikan berkualitas. Pertama, mengintegrasikan beragam subjek mata pelajaran menjadi suatu kegiatan belajar yang terpadu (integrated learning) dan dilakukan dengan menyenangkan (enjoy learning). Kedua, tidak melulu terlalu berorientasi pada kecerdasan siswa, namun pada penciptaan karakter mulia. Ketiga, menciptakan kesetaraan guru-murid sebagai subjek pembelajar, termasuk memahami murid sebagai pribadi yang unik dengan kecerdasan yang berbeda-beda. Ketiga unsur tersebut membutuhkan satu hal penting, yaitu guru-guru bijak dan berwawasan luas, yang tercipta karena kemampuan akademis bagus dan kaya pengalaman. ${ }^{1}$

Aplikasi pendidikan life skills dalam suatu lembaga pendidikan akan melahirkan output santri yang memiliki daya kompetisi yang tinggi. Dengan bekal life skills mereka akan lebih produktif dan mampu bersaing di dunia kerja, sehingga pesantren mengambil langkah tepat karena dapat membuktikan bahwa pesantren tersebut terbilang sebagai salah satu lembaga pendidikan yang berkualitas dan kompetitif. Hal tersebut terlihat proses pembelajarannya tidak hanya berorientasi pada kecerdasan siswa, tapi pada penciptaan karakter mulia. Selain itu, guru (ustaz) kebanyakan sudah menjadi sarjana bahkan sampai menjadi doktor. Hal ini menjadi kebanggaan tersendiri baik bagi santri maupun pengasuh pondok pesantren.

\footnotetext{
1 Jamal Ma'mur Asmani, Sekolah Life Skills, Lulus Siap Kerja! (Yogyakarta: Diva Press, 2009), 231.
} 
Sebagai lembaga pendidikan nonformal, Pondok Pesantren Darul Falah Be-Songo Ngaliyan Semarang telah menyelenggarakan kegiatankegiatan yang berwawasan kecakapan hidup (life skills). Dikatakan demikian karena di dalam pesantren tersebut tidak hanya diajarkan ilmuilmu agama semata, banyak cakupan life skills yang ditawarkan kepada santri, tidak hanya kecakapan secara umum, tetapi juga kecakapan secara spesifik. Kecakapan tersebut meliputi kecakapan vokasional dan kecakapan akademik. Kecakapan vokasional di sini berupa keterampilan memasak, menyulam, merias dan jenis kerajinan yang lain. Selain itu, di dalamnya juga diajarkan bagaiman para santri dapat berbicara dengan baik, baik dalam mengemukakan pendapat maupun dalam berpidato dan keterampilan lain yang menjadi daya tarik sendiri bagi masyarakat sekitar.

Pondok Pesantren Darul Falah Be-Songo Ngaliyan Semarang merupakan salah suatu lembaga pesantren yang menarik untuk dijadikan tempat atau tujuan penelitian. Hal itu karena pondok pesantren tersebut telah melaksanakan program-program yang berorientasi ke masa depan. Hal ini terlihat dalam beberapa program, di antaranya menerapkan kesatuan antara teori dan praktik, akademik yang totalitas, membentuk generasi Muslim yang Islami. Meskipun pesantren ini tergolong baru, namun pesantren ini mampu menerapkan pendidikan pesantren berbasis life skills dengan baik.

Dalam pesantren ini tidak hanya mengajarkan teori saja, tetapi juga mempraktikkannya untuk memecahkan problem kehidupan seharihari. Banyak pelatihan-pelatihan yang diikuti para santri yang akan menjadi bekal bagi mereka dalam menghadapi kehidupan riil. Secara rutin, pesantren ini mengadakan pelatihan untuk memanfaatkan waktu liburan karena pesantren ini dihuni oleh para mahasiswa, maka waktu liburan menjadi kesempatan emas bagi pesantren tersebut untuk mengisinya dengan pelatihan-pelatihan, seperti pelatihan memasak, pelatihan jurnalistik, komputer, dan resolusi konflik.

Sebenarnya di berbagai daerah sudah ditemukan pesantren yang memiliki corak yang sama dengan pesantren ini. Pesantren model ini 
terdapat di Yogyakarta Pondok Pesantren Hasyim Asy'ari, pesantren terebut mendapat perhatian publik secara luas, karena keunggulan kompetensi berbasis life skills yang diajarkan kepada anak-anak didiknya. ${ }^{2}$ Dalam Pondok pesantren ini santri diajarkan bagaimana menggunakan internet, menulis di majalah, menulis cerpen, membuat rekaman, dan karya-karya lain yang bermanfaat bagi masyarakat luas. Di Tangerang Pondok pesantren Daar el-Qalam dan di Jombang Pesantren al-Aqabah juga menerapkan sistem pendidikan berbasis life skills.

Meskipun lembaga pesantren tersebut menerapkan pendidikan berwawasan life skills, namun tidak meninggalkan tradisi pesantrennya. Hal ini didasarkan pada teori pesantren yang mengatakan bahwa pesantren merupakan salah satu bentuk lingkungan "masyarakat" yang unik dan memiliki tata nilai kehidupan yang positif. Selain itu, lembaga pesantren ini memiliki tujuan untuk mendalami ilmu agama Islam (tafaqquh $f i$ ad-din) dengan menekankan pentingnya moral dan pengalaman ajaran Islam dalam kehidupan bermasyarakat. ${ }^{3}$

Tradisi kepesantrenan ini dapat terlihat pada beberapa elemen yang kian kental dengan dunia pesantren, di antaranya, terdapat santri, kiai, masjid, pondok (asrama) dan kitab klasik. Selain itu, pesantren modern masih menggunakan beberapa metode khas pesantren yang terkenal dengan nama sorogan, halaqah, bahtsul masail, dan sebagainya. Selain elemen dan metode, Pesantren Hasyim Asy'ari juga menerapkan sistem kekeluargaannya.

Pesantren merupakan lembaga berperan ganda, yaitu pesantren sebagai pelaksana proses belajar mengajar ilmu agama Islam dan pesantren sebagai penyebar dakwah agama Islam. Dalam proses belajar mengajar di pesantren diajarkan bahwa Islam adalah agama yang mengatur urusan ibadah dan mu'amalah. Hal ini sangat berpengaruh terhadap perkembangan pribadi santrinya, bahkan sangat berpengaruh pada pribadi alumninya setelah mereka terjun hidup di tengah-tengah

\footnotetext{
2 Ibid., 240-241.

3 Ahmad Muthohar, Ideologi Pendidikan Pesantren: Pesantren di tengah Arus Ideologi-ideologi Pendidikan (Semarang: Pustaka Rizki Putra, 2007), 16-17.
} 
masyarakat.

Melalui pendidikan pesantren ini, seseorang dapat ikut serta membentuk pribadi Muslim yang tangguh, harmonis, mampu mengatur kehidupan pribadinya, mengatasi persoalan-persoalannya, mencukupi kebutuhan-kebutuhannya, serta mengendalikan dan mengarahkan kehidupannya. ${ }^{4}$ Sejak awal perkembangan hingga awal era 1970-an, pesantren pada umumnya dipahami sebagai lembaga pendidikan agama yang bersifat tradisional. Hal ini karena pesantren itu biasanya tumbuh dan berkembang di masyarakat pedesaan melalui proses sosial yang unik, proses pembelajarannya masih menggunakan sistem klasikal, metode yang digunakan pun masih tradisional. Pada saat itu pula pesantren tidak hanya berperan sebagai lembaga pendidikan, tetapi berperan sebagai lembaga sosial yang berpengaruh.

Keberadaan pondok pesantren dan masyarakat merupakan dua sisi yang tidak dapat dipisahkan. Keduanya saling mempengaruhi. Sebagian besar pesantren berkembang dari adanya dukungan masyarakat, dan bahkan tidak sedikit berdirinya pesantren merupakan inisiatif masyarakat. Begitu pula sebaliknya perubahan sosial dalam masyarakat merupakan dinamika kegiatan pondok pesantren dalam pendidikan dan kemasyarakatan. ${ }^{5}$

Selain itu, keberadaan pesantren memberikan pengaruh dan warna keberagamaan dalam kehidupan masyarakat sekitarnya. Pengaruh ini tidak hanya di wilayah administrasi pedesaan, tetapi sering kali hingga melintasi daerah kabupaten dimana pesantren itu berada. Oleh karena itu, pesantren sering menjadi agen perubahan (agent of change). Pesantren sebagai lembaga yang berperan sebagai dinamisator dan katalisator pemberdayaan sumber daya manusia, penggerak pembangunan di segala bidang, serta pengembang ilmu pengetahuan dan teknologi dalam

\footnotetext{
4 Muhtarom, "Urgensi Pesantren dalam Pembentukan Kepribadian Muslim," dalam Ismail SM, et.al., Dinamika Pesantren dan Madrasah (Yogyakarta: Pustaka Pelajar \& Fakultas Tarbiyah IAIN Walisongo Semarang, 2002), 39-49.

5 Bahri Gazali, Pendidikan Pesantren Berwawasan Lingkungan (Jakarta: Pedoman Ilmu Jaya, 2001), 13.
} 
menyongsong era global. Di sinilah perubahan merambah ke dalam dunia pesantren.

Sebagaimana diketahui, era global meniscayakan terjadinya peruabahan di segala aspek kehidupan, mulai dari perubahan orientasi, persepsi, dan tingkat selektivitas masyarakat terhadap pendidikan. Hal ini memaksa Indonesia untuk mengubah orientasi pendidikannya menuju pendidikan yang berorientasikan kualitas, kompetensi, dan skill.

Berkenaan dengan ini, standar mutu yang berkembang di masyarakat adalah tingkat keberhasilan lulusan sebuah lembaga pendidikan dalam mengikuti kompetisi pasar global. Selain itu, pesantren juga diharapkan mampu meningkatkan peran kelembagaan sebagai kawah candradimuka generasi muda Islam dalam menimba ilmu pengetahuan dan teknologi sebagai bekal dalam menghadapi era globalisasi. Untuk dapat menganalisis peran pesantren di era global, sebelumnya harus dipahami bahwa pesantren memiliki akar sosio-historis yang cukup kuat. Dengan demikian, pesantren mampu menduduki posisi yang relatif sentral dalam dunia keilmuan masyarakatnya, dan sekaligus bertahan di tengah berbagai gelombang perubahan. ${ }^{6}$ Hanya saja, selama ini berkembang anggapan bahwa pondok pesantren cenderung tidak dinamis dan tertutup terhadap segala perubahan atau modernisasi. Anggapan ini pula yang menyebabkan lembaga pendidikan pondok pesantren (terutama yang tidak memiliki madrasah) diidentikkan dengan tradisionalisme, dan tidak sejalan dengan proses modernisasi. Akibatnya, perhatian pada pengembangan pondok pesantren lebih dilihat dalam perspektif kesediaannya menjadi lembaga pendidikan agama. Permasalahan dalam dunia pendidikan pesantren demikian kompleks. Sebagaimana dikemukakan Azyumardi Azra, permasalahan tersebut tidak mungkin dapat dipecahkan hanya sekedar melalui perluasan (ekspansi) linier dari sistem pendidikan yang ada. Hal itu juga tidak bisa dipecahkan dengan jalan penyesuaian teknis administratif di sana-sini. Bahkan, permasalahan tersebut tidak dapat diselesaikan pula dengan pengalihan konsep pen-

\footnotetext{
6 Amin Haedari, et.al, Masa Depan Pesantren dalam Tantangan Modernitas dan Tantangan Kompleksitas Global, Cet. I (Jakarta: IRD Press, 2004), 185.
} 
didikan dari teknologis pendidikan yang berkembang demikian pesat. Lebih dari semua itu, yang diperlukan sekarang adalah menjamin kembali konsep dan asumsi yang mendasari seluruh sistem pendidikan Islam, baik secara makro maupun mikro.

Sejalan dengan itu, mengembalikan pesantren kepada fungsi pokok yang sebenarnya juga harus segera diwujudkan. Sebagaimana diketahui, setidaknya terdapat tiga fungsi pokok pesantren: transmisi ilmu pengetahuan Islam, pemeliharaan tradisi Islam, dan pembinaan calon-calon ulama. Dalam hal ini pesantren dituntut melakukan terobosan-terobosan sebagai berikut: pertama, membuat kurikulum terpadu, gradual, sistematik, egaliter, dan bersifat buttom up (tidak top down). Artinya, penyusunan kurikulum tidak lagi didasarkan pada konsep plain for student (pembiasaan untuk peserta didik) tapi plain by student (pembiasaan oleh peserta didik). Kedua, melengkapi sarana penunjang proses pembelajaran. Ketiga, memberikan kebebasan kepada santri yang ingin mengembangkan talenta mereka masing-masing, baik yang berkenaan dengan pemikiran, ilmu pengetahuan, teknologi, maupun kewirausahaan. Keempat, menyediakan wahana aktualisasi diri di tengah-tengah masyarakat. $^{7}$

Peran pondok pesantren yang sebelumnya hanya mempelajari kitabkitab Islam klasik harus segera direkonstruksi agar dapat didayagunakan secara maksimal. Dengan cara ini, sumber daya atau unsur-unsur pondok pesantren termasuk guru atau kiai, masjid, santri, kitab kitab klasik hingga ilmu pengetahuan yang baru dapat didayagunakan dalam proses pendidikan life skills secara berkelanjutan untuk membangun manusia yang memiliki paham ilmu pengetahuan, potensi kemasyarakatan, dan pembangunan wilayah. Karekteristik masyarakat yang mengharapkan sebagaimana diatas membawa implikasi bahwa paradigma pendidikan saat ini harus bermuara pada peningkatan dan pengembangan life skills yang diwujudkan melalui pencapaian kompetensi peserta didik untuk mampu menghadapi sekaligus mampu memecahkan problem-problem kehidupan. Begitu juga yang diharapkan oleh pendiri dan pengasuh

\footnotetext{
7 Haedari, et.al., Masa Depan Pesantren, 198-199.
} 
Pondok Pesantren Darul Falah Be-Songo Ngaliyan Semarang. Pesantren ini selain berorientasi pada penguasaan ilmu-ilmu keagamaan juga berorientasi pada kecakapan untuk hidup yang sengaja dirancang untuk membekali para santri agar berani menghadapi tantangan hidup sekaligus tantangan global.

\section{Pendidikan Life Skills di Pesantren}

Terdapat perbedaan pendapat tentang pengertian pendidikan life skills atau pendidikan kecakapan hidup, namun esensinya tetap sama. Menurut Malik Fajar, life skills adalah kecakapan yang dibutuhkan untuk bekerja selain kecakapan dalam bidang akademik. Sementara itu Team Broad Based Education Depdiknas mendefinisikan life skills sebagai kecakapan yang dimiliki oleh seseorang agar berani dan mau menghadapi segala permasalahan kehidupan dengan aktif dan proaktif sehingga dapat menyelesaikannya. ${ }^{8}$ Slamet $\mathrm{PH}$ mendefinisikan life skills sebagai kemampuan, kesanggupan, dan keterampilan yang diperlukan oleh seseorang untuk menjalankan kehidupan dengan nikmat dan bahagia. Kecakapan tersebut mencakup segala aspek sikap dan perilaku manusia sebagai bekal untuk menjalankan kehidupannya. Penjelasan pasal 26 ayat 3 UU No. 20 Tahun 2003 tentang Sistem Pendidikan Nasional menyebutkan bahwa pendidikan kecakapan hidup (life skill education) adalah pendidikan yang memberikan kecakapan personal, sosial, intelektual, dan kecakapan vokasional untuk bekerja atau usaha mandiri.

Dari beberapa pendapat di atas, pendidikan life skills dapat diartikan sebagai pendidikan yang memberikan bekal dasar dan latihan yang dilakukan secara benar kepada peserta didik tentang nilai-nilai kehidupan yang dibutuhkan dan berguna bagi perkembangan kehidupan peserta didik. Dengan demikian, pendidikan life skills harus dapat merefleksikan kehidupan nyata dalam proses pengajaran agar peserta didik memperoleh kecakapan hidup di tengah-tengah masyarakat. Pendidikan kecakapan hidup (life skills) sebenarnya bukan merupakan hal baru bagi

\footnotetext{
8 Asmani, Sekolah Life Skills, 30.
} 
pesantren, sebab sejak dahulu jenis pendidikan ini memang menjadi andalan bagi pesantren.

Namun, dengan perkembangan ilmu pengetahuan dan teknologi yang pesat pada era global ini, pendidikan kecakapan hidup yang dilaksanakan secara tradisional di lingkungan pesantren perlu mendapatkan sentuhan teoretis dan teknis sehingga para alumni lembaga pendidikan lainnya dalam berebut lapangan pekerjaan yang semakin lama semakin kuat. Pendidikan life skills di pesantren ini sebenarnya diadopsi dari teori pendidikan life skills dalam pendidikan formal. Dikatakan demikian, karena pada dasarnya pendidikan life skills diterapkan itu memiliki tujuan yang sama, yakni menyiapkan peserta didik (santri) agar mampu, sanggup, serta terampil menjaga kelangsungan hidup dan perkembangannya di masa datang.

Secara umum dapat dikemukakan, tujuan dari penyelenggaraan life skills di lingkungan pesantren adalah untuk membantu para santri mengembangkan kemampuan berpikir, menghilangkan pola pikir atau kebiasaan yang kurang tepat, dan mengembangkan potensi diri agar dapat memecahkan problema kehidupan secara konstruktif, inovatif, dan kreatif sehingga dapat menghadapi realitas kehidupan dengan bahagia, baik secara lahiriah maupun batiniah. ${ }^{9}$

Meskipun pelaksanaan pendidikan life skills di pesantren dapat bervariasi, namun perlu diingat bahwa pendidikan life skills harus akrab lingkungan dan fungsional. Artinya, life skills harus disesuaikan dengan kondisi santri dan lingkungan, serta memenuhi prinsip-prinsip umum yang harus dipegang ketika pensantren menyelenggarakan integrasi dengan pendidikan life skills, yaitu: ${ }^{10}$

a. Tidak mengubah sistem pendidikan yang berlaku.

b. Tidak harus mengubah kurikulum tetapi yang harus dilakukan adalah penyiasatan kurikulum untuk diorientasikan pada

9 M. Sulthon Masyhud \& Moh Khusnurdilo, Manajemen Pondok Pesantren (Jakarta: Diva Pustaka 2004), 163.

${ }^{10}$ Ibid., 163-164. 
kecakapan hidup.

c. Etika sosio-religius bangsa tidak boleh dikorbankan dalam pendidikan kecakapan hidup (life skills), melainkan justru sedapat mungkin diintegrasikan dalam proses pendidikan.

d. Pembelajaran kecakapan hidup menggunakan prinsip learning to know, learning to do, learning to be, dan learning to life together.

e. Pelaksanaan life skills di pesantren menerapkan Manajemen Berbasis Pondok Pesantren (MBPP).

f. Potensi daerah sekitar dapat direfleksikan dalam penyelenggaraan pendidikan sesuai dengan pendidikan kontekstual dan pendidikan berbasis luas.

g. Paradigma learning for life and learning to work dapat dijadikan sebagai dasar pendidikan, sehingga terjadi pertautan antara pendidikan dan kehidupan nyata peserta didik (santri).

h. Penyelenggaraan pendidikan senantiasa diarahkan agar santri.

i. Menuju hidup sehat dan berkualitas.

j. Mendapatkan pengetahuan, wawasan, dan keterampilan yang luas.

k. Memiliki akses untuk memenuhi standar hidupnya secara layak. ${ }^{11}$

\section{Tujuan dan Maniaat Pendidikan Life Skills di Pesantren}

Secara umum pendidikan yang berorientasi pada kecakapan hidup bertujuan memfungsikan pendidikan sesuai dengan fitrahnya, yaitu mengembangkan potensi manusiawi peserta didik untuk menghadapi perannya di masa mendatang. ${ }^{12}$ Secara khusus pendidikan yang berorientasi pada kecakapan hidup bertujuan untuk:

${ }^{11}$ Ibid.

${ }^{12}$ Tim Broad Based Education Depdiknas, Kecakapan Hidup Melalui Pendekatan Pendidikan Berbasis Luas (Surabaya: Surabaya Intellectual Club (SIC) \& Lembaga Pengabdian Masyarakat Universitas Negeri Surabaya, 2002), 7-8. 
a. Mengaktualisasikan potensi peserta didik sehingga dapat digunakan untuk memecahkan problema yang dihadapi.

b. Memberikan kesempatan kepada sekolah untuk mengembangkan pembelajaran yang fleksibel sesuai dengan prinsip pendidikan berbasis luas.

c. Mengoptimalkan pemanfaatan sumber daya di lingkungan sekolah, dengan memberi peluang pemanfaatan sumber daya yang ada di masyarakat, sesuai dengan prinsip manajemen berbasis sekolah.

Sedangkan tujuan dari penyelenggaraan kecakapan hidup (life skills) di lingkungan pesantren adalah untuk membantu peserta didik (para santri) mengembangkan kemampuan berpikir, menghilangkan pola berpikir atau kebiasaan yang kurang tepat, dan mengembangkan potensi diri agar dapat memecahkan problema kehidupan secara konstruktif, inovatif, dan kreatif sehingga dapat menghadapi realitas kehidupan dengan bahagia, baik secara lahiriah maupun batiniah. ${ }^{13}$ Dari beberapa tujuan yang ada hampir semua pendidikan kecakapan hidup (life skills) itu memiliki tujuan yang hampir serupa yakni mengembangkan kecakapan peserta didik atau santri agar mereka dapat mengambil keputusan untuk memecahkan masalah yang mereka hadapi. Pendidikan life skills merupakan trobosan progresif bagi dunia pendidikan di negeri ini, sehingga harus dimanfaatkan secara maksimal. Manfaat dari pendidikan life skills ini luar biasa bagi dinamisasi dan revitalisasi dunia pendidikan di tengah kompetensi massif di segala aspek kehidupan sekarang ini.

Secara umum manfaat pendidikan kecakapan hidup bagi peserta didik adalah sebagai bekal dalam menghadapi dan memecahkan problem hidup dan kehidupan, baik secara pribadi yang mandiri, warga masyarakat, maupun sebagai warga negara. Manfaat lain pendidikan kecakapan hidup adalah bagi pribadi santri di antaranya pendidikan life skills dapat meningkatkan kualitas berpikir, kualitas kalbu, dan kualitas fisik. Selain itu, bagi lingkungan di mana santri itu berada atau bagi

\footnotetext{
${ }^{13}$ Masyhud \& Khusnurdilo, Manajemen Pondok, 163.
} 
masyarakat dapat meningkatkan kehidupan yang maju dan madani. Hal itu dapat ditandai dengan beberapa indikator, yaitu peningkatan kesejahteraan sosial, pengurangan perilaku destruktif sehingga dapat mereduksi masalah-masalah sosial, dan pengembangan masyarakat secara harmonis.

\section{Insur-unsur Pendidikan Life Skills di Pesantren}

\section{Kiai dan Ustaz}

Kata kiai dalam terminologi Jawa memiliki makna sesuatu yang diyakini memiliki tuah atau keramat. Artinya, segala sesuatu yang memiliki keistimewaan dan keluarbiasaan dibandingkan dengan yang lain. Kiai atau pengasuh pondok pesantren merupakan elemen yang sangat esensial bagi suatu pesantren. Rata-rata pesantren yang berkembang di Jawa dan Madura sosok kiai begitu sangat berpengaruh, kharismatik, dan wibawa sehingga amat disegani oleh masyarakat di lingkungan pesantren. Kiai pada hakikatnya adalah gelar yang diberikan kepada seseorang yang mempunyai ilmu di bidang agama dalam hal ini agama Islam. Terlepas dari anggapan kiai sebagai gelar yang sakral, maka sebutan kiai muncul di dunia pondok pesantren. ${ }^{14}$ Eksistensi pesantren, nyaris tidak dapat sepenuhnya lepas dari pembahasan tentang peran kiai. Sebab, kiai merupakan leader, di mana pesantren berdialektika dan menggagas peran-peran pentingnya dalam perjalanan sejarah Islam nusantara. ${ }^{15}$ Keberadaan kiai dalam pesantren sangat sentral sekali. Suatu lembaga pendidikan Islam disebut pesantren apabila memiliki tokoh sentral yang disebut kiai. Jadi, kiai di dalam dunia pesantren sebagai penggerak dalam mengemban dan mengembangkan pesantren sesuai dengan pola yang dikehendaki. Unsur pesantren lainnya adalah guru atau ustaz. Ustaz adalah santri kiai yang dipercayai untuk mengajar agama kepada santri dan dibimbing atau

\footnotetext{
${ }^{14}$ Bahri Gazali, Pendidikan Pesantren Berwawasan Lingkungan (Jakarta: Pedoman Ilmu jaya, 2001), 21.

${ }^{15}$ Ibnu Hajar, Kiai di Tengah Pusaran Politik (Jakarta: IRCiSoD, 2009), 18.
} 
disupervisi oleh kiai. ${ }^{16}$ Ustaz dalam kehidupan pesantren mengalami beberapa tantangan antara lain mengabdi, mencari nafkah dan mengejar karier. $^{17}$

\section{Santri}

Santri adalah siswa atau murid yang belajar di pesantren. Seorang ulama bisa disebut kiai kalau memiliki pesantren dan santri yang tinggal dalam pesantren tersebut untuk mempelajari ilmu-ilmu agama Islam melalui kitab-kitab kuning. Oleh karena itu, eksistensi kiai biasanya juga berkaitan dengan adanya santri di pesantrennya. Istilah santri hanya terdapat di pesantren sebagai pengejawantahan adanya peserta didik yang haus akan ilmu pengetahuan yang dimiliki oleh seorang kiai yang memimpin sebuah pesantren. Oleh karena itu, santri pada dasarnya berkaitan erat dengan keberadaan kiai dan pesantren. ${ }^{18}$ Dalam dunia pesantren istilah santri diklasifikasikan menjadi dua golongan, antara lain:

a. Santri mukim adalah murid-murid yang berasal dari daerah yang jauh yang menetap dalam kelompok pesantren. Bagi pesantren yang besar, santri-santrinya berasal dari hampir seluruh nusantara dan bahkan banyak dari negara tetangga.

b. Santri kalong adalah murid-murid yang berasal dari desadesa sekeliling pesantren yang biasanya tidak menetap dalam pesantren. Mereka hanya belajar di pesantren dan setelah selesai waktunya mereka pulang ke rumah masing-masing. ${ }^{19}$

\section{Materi Life Skills di Pesantren}

Sebagai lembaga pendidikan Islam, pesantren pada dsarnya hanya mengajarkan agama, sedangkan sumber kajian atau mata pelajarannya

\footnotetext{
${ }^{16}$ Muthohar, Ideologi Pendidikan Pesantren, 33.

${ }^{17}$ Ibid., 33-34.

${ }^{18}$ Bahri Gazali, Pendidikan Pesantren Berwawasan (Jakarta: Pedoman Ilmu Jaya, 2001), 2223.

${ }^{19}$ Muthohar, Ideologi Pendidikan Pesantren, 34.
} 
adalah kitab-kitab dalam bahasa Arab. Pelajaran agama yang dikaji di pesantren ialah al-Qur'an dengan tajwidnya dan tafsirnya, aqaid dan ilmu kalam, fikih dan ushul fikih, dan sebagainya. ${ }^{20}$ Berbeda dengan pesantren berwawasan kecakapan hidup (life skills). Di dalam pesantren tersebut tidak hanya mengajarkan agama semata akan tetapi adanya keseimbangan antara materi duniawi dan ukhrowi karena di dalamnya diajarkan bagaimana cara menyikapi permasalahan yang ada, mengembangkan potensi, dan diajari bagaimana caranya agar bisa survive di masa mendatang.

Adapun cakupan materi pendidikan life skills di pesantren adalah sebagai berikut:

\section{a. Kecakapan Personal (Self Awarness)}

Kecakapan personal yaitu suatu kemampuan berdialog yang diperlukan oleh seseorang untuk dapat mengaktualisasikan jati diri dan menemukan kepribadiannya dengan cara menguasai serta merawat raga dan jiwa atau jasmani dan rohani. ${ }^{21}$ Kesadaran diri sebagai hamba Allah Swt. Agama Islam yang diturunkan sesuai dengan tingkat perkembangan masyarakat adalah agama yang sesuai dengan fitrah tersebut. Dan selalu meningkatkan manusia kepada fitrahnya. Fitrah manusia sebagai makhluk sosial dan anggota lingkungannya diingatkan oleh Allah untuk selalu mengemban amanah-Nya, yaitu untuk memanfaatkan dan sekaligus menyejahterakan alam, lingkungan sosial, dan dirinya sendiri menuju kesempurnaan. Pengabdiannya dalam menjalankan amanah sesuai dengan ajaran agama, pada hakikatnya merupakan wujud ketaatan kepada Allah yang dinilai sebagai ibadah. Inilah tujuan hidup manusia, yakni

${ }^{20}$ Abuddin Nata, Sejarah Pertumbuhan dan Perkembangan Lembaga-Lembaga Pendidikan Islam di Indonesia (Jakarta: PT Grafindo, 2001), 107.

${ }^{21}$ Departemen Agama Direktorat Jenderal Kelembagaan Agama Islam, Pedoman Integrasi Pendidikan Kecakapan Hidup (Life Skills) dalam Pembelajaran Madrasah Ibtidaiyah dan Madrasah Tsanawiyah (Jakarta: Departemen Agama Direktorat Jendral Kelembagaan Agama Islam, 2005), 13 
untuk beribadah kepada-Nya. Kesadaran akan potensi diri. Setiap manusia hendaknya menyadari dan mensyukuri atas kelebihan dan kekurangan jasmani-rohani yang dimiliki, yang diwujudkan dalam bentuk kesediaan menjaga kebersihan dan kesehatan, menjaga keseimbangan dengan mengukur kemampuan diri, merasa cukup (qanaah), percaya diri, bertindak tepat dan proporsional (adil), berkemauan untuk mengembangkan diri, serta bertanggung jawab.

\section{b. Kecakapan Berpikir Rasional (Thinking Skills)}

Islam menggambarkan bahwa salah satu keunggulan potensi insaniyah adalah akal untuk berpikir dan mempertimbangkan tindakannya secara cerdas. Kesadaran insani yang berupa kecerdasan akal ini merupakan anugrah yang tidak terhitung nilainya, karenanya Allah memuliakan manusia di atas makhluk lainnya. Alam dan seisinya serta kehidupan yang ada di dalamnya merupakan amanah Allah yang diberikan kepada manusia, disediakan sebagai fasilitas dan menantang hidupnya agar menggali ilmu pengetahuan, mengolah dan menggali ilmu pengetahuan, mengolah dan mengambil manfaat, memecahkan masalah dan mengambil keputusan yang tepat demi meraih kesejahteraan dan mewujudkan kemashlahatan di dalamnya. Kecakapan ini meliputi:

1) Kecakapan menggali informasi.

2) Kecakapan mengelola informasi.

3) Kecakapan mengambil keputusan.

4) Kecakapan memecahkan masalah.

\section{c. Kecakapan Sosial (Social Skills)}

Sebagai mahluk sosial manusia tidak dapat hidup sendiri, ia membutuhkan bantuan orang lain, tidak hanya sebagai teman dalam kesendirian, tetapi juga sebagai partner dalam melakukan sesuatu, baik itu aktivitas ekonomi, sosial, budaya, politik maupun amal perbuatan yang terkait dengan ibadah kepada Tuhan. Sehingga dari 
sinilah tercipta hubungan untuk tolong menolong antar manusia. ${ }^{22}$ Allah berfirman dalam Q.S. al-Maidah ([5]: 2), "Dan tolong-menolonglah kamu dalam mengerjakan kebajikan dan takwa, dan jangan tolong-menolong dalam berbuat dosa dan pelanggaran dan bertakwalah kamu kepada Allah, sesungguhnya Allah amat berat siksanya." Kecakapan sosial meliputi:

1) Kecakapan berkomunikasi dengan empati antara lain dapat dikembangkan melalui bercerita, mendengarkan orang lain, menuangkan gagasan melalui tulisan, gambaran dan sebagainya.

2) Kecakapan bekerjasama, dapat dikembangkan melalui kerja kelompok, menjadi anggota kelompok dan pemimpin kelompok, bergotong royong membersihkan ruangan, halaman dan lingkungan pesantren, dan sebagainya.

\section{d. Kecakapan Pra-Vokasional (Pre-Vocational Skills)}

Seperti yang telah dijelaskan di atas bahwa kecakapan vokasional ini sering disebut kecakapan kejuruan, artinya kecakapan yang dikaitkan dengan bidang pekerjaan tertentu yang terdapat di masyarakat. ${ }^{23}$ Jadi, kecakapan pra-vokasional merupakan kecakapan yang harus dimiliki seseorang sebelum dia menguasai kecakapan vokasional atau kecakapan kejuruan. Unsur-unsur kecakapn ini antara lain meliputi:

1) Koordinasi mata, tangan dan mata kaki, antara lain dikembangkan melalui menggambar, menulis, melempar, bermain, menangkap bola, dan sebagainya.

2) Keterampilan lokomotor, dapat dikembangkan antara lain melalui berjalan, berbaris, lari, melompat, merayap dan

${ }^{22}$ Misbahul Munir, “Tolong Menolong dalam Kehidupan Santri: Studi Kasus di Pondok Pesantren Darun Najah Tugu Semarang," Skripsi, IAIN Walisongo Semarang, 14.

${ }^{23}$ Asmani, Sekolah Life Skills, 56. 
sebagainya.

3) Keterampilan non-lokomotor, dapat dikembangkan antara lain melalui berbagai gerakan tubuh, senam, dan sebagainya.

\section{e. Keterampilan Keahlian Khusus}

Keterampilan ini merupakan keterampilan dalam pendalaman satu atau beberapa jenis keterampilan tertentu, yang nantinya akan menjadi keterampilan siap pakai dalam kehidupan di masyarakat. Pemilihan keterampilan ini harus akrab lingkungan dan fungsional.

\section{Metode}

Secara etimologis metode berasal dari kata met dan hodes yang berarti melalui. Sedangkan secara istilah, metode adalah jalan atau cara yang harus ditempuh untuk mencapai suatu tujuan. Sedangkan pembelajaran berarti kegiatan belajar mengajar yang interaktif yang terjadi antara santri sebagai peserta didik (muta'allim) dan kiai atau ustaz di pesantren sebagai pendidik (learner atau mu'allim) yang diatur berdasarkan kurikulum yang telah disusun dalam rangka mencapai tujuan tertentu. ${ }^{24}$ Dengan demikian, yang dimaksud dengan metode pembelajaran adalah cara-cara yang mesti ditempuh dalam kegiatan belajar mengajar antara santri dan kiai untuk mencapai suatu tujuan tertentu.

Dalam menyajikan materi tidak berarti apapun tanpa melibatkan metode. Metode selalu mengikuti materi, dalam arti menyesuaikan dengan bentuk dan coraknya, sehingga metode mengalami transformasi bila materi yang disampaikan berubah. Akan tetapi, materi yang sama bisa dipakai metode yang berbeda-beda. Seperti halnya materi, pada hakikatnya metode hanya sebagai alat, bukan tujuan. Untuk merealisir tujuan sangat dibutuhkan alat. Bahkan alat merupakan syarat mutlak

\footnotetext{
${ }^{24}$ Tim Direktorat Jendral Kelembagaan Agama Islam Bekerja Sama dengan Direktorat Pendidikan Keagamaan dan Pondok Pesantren dan Proyek Peningkatan Pendidikan Luar Sekolah pada Pondok Pesantren, Pola Pembelajaran di Pesantren (Jakarta: Dirjen Kelembagaan Agama Islam, 2003), 73.
} 
bagi setiap kegiatan pendidikan dan pengajaran. Bila kiai maupun ustaz mampu memilih metode dengan tepat dan mampu menggunakannya dengan baik, maka mereka memiliki harapan besar terhadap hasil pendidikan dan pengajaran yang dilakukan. ${ }^{25}$

Sebagai lembaga pendidikan Islam, pesantren pada dasarnya hanya mengajarkan agama, sedangkan kajian atau mata pelajarannya ialah kitab-kitab dalam bahasa Arab (kitab kuning). Adapun metode yang lazim digunakan dalam pendidikan pesantren ialah: ${ }^{26}$

\section{a. Wetonan atau Bandongan}

Sistem weton atau bandongan, yaitu dimana para santri mengikuti pelajaran dengan duduk di sekeliling kiai atau dalam ruangan (kelas) dan kiai menerangkan pelajaran secara kuliah. Para santri menyimak kitab masing-masing dan membantu catatan atau ngesahi (Jawa: mengesahkan), dengan memberi catatan pada kitabnya, untuk mensahkan bahwa ilmu itu telah diberikan oleh kiai. Sistem weton adalah sistem yang tertua di pondok pesantren menyertai sistem sorogan dan tentunya merupakan inti dari pengajaran di suatu pesantren. Wetonan atau bandongan dilakukan dalam rangka memenuhi kompetensi kognitif santri dan memperluas referensi keilmuan bagi mereka. ${ }^{27}$ Sistem weton membutuhkan sarana yang tetap berupa ruangan (kelas) sebagaimana sistem madrasah, karena jumlah pengikutnya jauh lebih besar dari sistem sorogan.

\section{b. Sorogan}

Istilah sorogan berasal dari kata sorog (Jawa) yang berarti menyodorkan. Sebab setiap santri secara bergiliran menyodorkan kitabnya

${ }^{25}$ Mujamil Qomar, Pesantren: Dari Transformasi Metodologi Menuju Demokratisasi Institusi (Jakarta: PT. Gelora Aksara Pratama), 141.

${ }^{26}$ Samsul Nizar, Sejarah Pendidikan Islam: Menelusuri Jejak Sejarah Pendidikan Era Rosulullah Sampai Indonesia (Jakarta: Kencana, 2007), 287.

${ }^{27}$ Dian Nafi, dkk., Praksis Pembelajaran Pesantren (Yogyakarta: PT. LKiS, 2007), 67. 
di hadapan kiai atau badal (pembantunya). Sistem ini tetap dipertahankan oleh pondok-pondok pesantren karena banyak manfaat dan faedah yang mendorong para santri untuk lebih giat dalam mengkaji dan memahami kitab-kitab kuning yang mempunyai nilai tinggi dalam kehidupan manusia. Sistem ini membutuhkan ketekunan, kesabaran, kerajinan, ketaatan, dan kedisiplinan tinggi dari santri. Pelaksanaan sistem sorogan ini, antarguru dan murid harus samasama aktif. Oleh karena itu, ketika pelajaran sedang berlangsung maka terjadi interaksi belajar mengajar secara langsung, tatap muka.

\section{c. Haialan}

Metode hafalan yang diterapkan di pesantren umumnya dipakai untuk menghafal kitab-kitab tertentu; metode hafalan juga sering diterapkan untuk pembelajaran al-Qur'an Hadis. Dalam pembelajaran al-Qur'an, metode ini biasa disebut metode tahfidzul al-Qur'an. ${ }^{28}$

\section{d. Halaqoh}

Halaqah merupakan kelompok kelas dari sistem bandongan. Halaqoh berarti lingkaran murid, atau sekelompok santri yang belajar di bawah bimbingan seorang ustaz dalam satu tempat. Dalam praktiknya, halaqah dikategorikan sebagai diskusi untuk memahami isi kitab, bukan mempertanyakan kemungkinan benar salahnya dari yang diajarkan oleh ustaz atau kiai dalam kitab.

\section{e. Fathul Kutub}

Fathul kutub merupakan kegiatan latihan membaca kitab (terutama kitab klasik) yang pada umumnya ditugaskan kepada santri senior di pondok pesantren. Sebagai sebuah metode fathul kutub bertujuan menguji kemampuan mereka dalam membaca kitab kuning. Khususnya setelah mereka menyelesaikan mata pelajaran kaidah bahasa Arab dengan kata lain fathul kutub menjadi wahana aktual-

${ }^{28}$ Amin Haedar, dkk., Masa Depan Pesantren dalam Tantangan, 97. 
isasi kemampuan para santri, khususnya dalam penguasaan ilmu kaidah bahasa Arab, di samping beberapa disiplin ilmu keagamaan lainnya sesuai dengan materi kitab yang ditugaskan untuk dibaca, baik itu akidah, fikih, hadis, tafsir, tasawuf, dan sebagainya.

Secara metodik, pendidikan dan pengajaran dalam pesantren diberikan dalam bentuk sorogan, bandongan, halaqah dan hafalan. Metode mengajar sorogan dan bandongan menjadi ciri khas pesantren dan sebagian para pakar pendidikan menganggap metode tersebut merupakan metode yang statis dan tradisional. Namun, bukan berarti tidak menerima inovasi. Metode sorogan justru mengutamakan kematangan, perhatian, dan kecakapan seseorang. ${ }^{29}$ Metode yang diterapkan pesantren pada prinsipnya mengikuti selera kiai, yang dituangkan dalam kebijakan-kebijakan pendidikannya.

Dari perspektif metodik, pesantren terpolarisasikan menjadi tiga kelompok: (a) kelompok pesantren yang hanya menggunakan metode yang bersifat tradisional dalam pengajaran kitab-kitab Islam klasik, (b) kelompok pesantren yang hanya menggunakan metode-metode hasil penyesuaian dengan metode yang dikembangkan pendidikan formal, dan (c) kelompok pesantren yang menggunakan metode-metode yang bersifat tradisional dan mengadakan penyesuaian dengan metode pendidikan yang dipakai dalam pendidikan formal. ${ }^{30}$

\section{Sarana Prasarana Pendidikan Life Skills}

Pendidikan life skills membutuhkan sarana prasarana yang representatif untuk menggugah semangat anak didik (santri) dalam menggali dan mengembangkan potensinya. Diperlukan peralatan yang disesuaikan dengan spesifikasi skills yang diharapkan. ${ }^{31}$ Hal yang harus menjadi catatan ialah jangan sampai peralatan dan perlengkapan yang diperlukan

\footnotetext{
${ }^{29}$ Muthohar, Ideologi Pendidikan Pesantren, 27-28.

${ }^{30}$ Qamar, Pesantren, 150.

${ }^{31}$ Asmani, Sekolah Life Skill, 153-154.
} 
itu tidak tersedia ketika proses pembelajaran dilaksanakan. ${ }^{32}$ Melihat betapa pentingnya sarana prasarana dalam pembelajaran, kiranya sangat penting untuk menyiapkan hal-hal yang diperlukan dalam pembelajaran agar tidak mengganggu berlangsungnya kegiatan pembelajaran tersebut.

\section{Evaluasi}

Evaluasi adalah cara penilaian yang dilakukan oleh seorang ustaz untuk mengetahui kemampuan santri dalam aspek pengetahuan (kognisi) aspek sikap (afeksi) dan aspek keterampilan (skill) terhadap materi pembelajaran yang telah diberikannya. ${ }^{33}$ Penilaian dilakukan di samping berguna untuk mengetahui tingkat perkembangan kemampuan penguasaan santri juga berfungsi sebagai umpan balik (feedback) bagi seorang kiai atau ustaz untuk meninjau kembali cara-cara yang dilakukannya berkenaan dengan penggunaan suatu metode pembelajaran tertentu. Oleh karena itu, keberhasilan pembelajaran kepada para santri amat ditentukan kemampuan belajar santri dan kemampuan membimbing kiai atau ustaz.

\section{Pelaksanaan Pendidikan Life Skills di Pesantren}

Pelaksanaan pendidikan life skills di pesantren ini terdapat tiga tahap, yakni tahap perencanaan, tahap pelaksanaan dan tahap evaluasi.

\section{Tahap Perencanaan}

Menurut Gaffar, perencanaan itu dapat diartikan sebagai proses penyusunan berbagai keputusan yang akan dilakukan pada masa yang akan datang untuk mencapai tujuan yang ditentukan. Selain itu, perencanaan merupakan proses penetapan dan pemanfaatan sumber-sumber daya secara terpadu yang diharapkan dapat menunjang kegiatan-kegiatan dan upaya-upaya yang akan dilakukan secara efektif dan efisien dalam

\footnotetext{
${ }^{32}$ Suherman, Desain Pembelajaran, 56.

${ }^{33}$ Dirjen Kelembagaan Agama Islam, Pola Pembelajaran, 82.
} 
mencapai tujuan. ${ }^{34}$ Dengan demikian, perencanaan adalah sasaran untuk bergerak dari keadaan masa kini ke suatu keadaan di masa mendatang sebagai suatu proses yang menggambarkan kerja sama untuk mengembangkan upaya peningkatan organisasi secara menyeluruh. Perencanaan pendidikan Islam adalah proses mempersiapkan secara sitematis kegiatan-kegiatan yang akan datang untuk mencapai sasaran atau tujuan pendidikan Islam yang telah dirumuskan dan ditetapkan sebelumnya. ${ }^{35}$ Terdapat suatu kalimat bijak "keberhasilan suatu kegiatan akan sangat tergantung kepada kematangan perencanaan". Substansi kalimat tersebut mengandung makna bahwa segala sesuatu harus direncanakan dengan matang. ${ }^{36}$ Demikian juga dalam pendidikan life skills, segala sesuatunya harus direncanakan dengan baik. Adapun langkah-langkah perencanaan dalam rangka melaksanakan pendidikan life skills di pesantren adalah menetapkan tujuan pendidikan life skills, mengidentifikasi kebutuhan, dam menyusunan kurikulum pendidikan life skills.

Tujuan penyelenggaraan kecakapan hidup (life skills) di lingkungan pesantren adalah untuk membantu para santri mengembangkan kemampuan berpikir, menghilangkan pola pikir atau kebiasaan yang kurang tepat, mengembangkan potensi diri agar dapat memecahkan problema kehidupan secara konstruktif, inovatif, dan kreatif sehingga dapat menghadapi realitas kehidupan dengan bahagia, baik secara lahiriah maupun batiniah. ${ }^{37}$

a. Mengidentifikasi Kebutuhan. Tahapan ini dilakukan agar dapat diketahui apa yang menjadi kebutuhan dalam proses pelaksanaan pendidikan life skills sehingga dapat memperlancar proses pembelajaran. Lancarnya proses pembelajaran dapat mempermudah

${ }^{34}$ Syaiful Sagala, Administrasi Pendidikan Kontemporer (Bandung: CV. Alfabeta, t.t), 47.

${ }^{35}$ Sujari, Pendidikan Pondok Pesantren Tradisonal dalam Persepktif Pendidikan Islam Indonesia (Jember: Sekolah Tinggi Agama Islam Negeri Jember, 2008); Dapat diakses pada www.scribd.com/doc/2978118/skripsi-pendidikan 08.1426042011

${ }^{36}$ Suherman, Desain Pembelajaran, 137.

${ }^{37}$ Masyhud \& Khusnurdilo, Manajemen Pondok, 163. 
pencapaian tujuan pendidikan life skills.

b. Penyusunan Kurikulum. Istilah kurikulum memang tidak begitu terkenal dalam dunia pesantren, meskipun sebenarnya materi telah ada dalam praktik pengajaran, bimbingan rohani, dan latihan kecakapan dalam kehidupan sehari-hari di pesantren. Itulah sebabnya pondok pesantren umumnya tidak merumuskan dasar dan tujuan pendidikan secara eksplisit. Ataupun mengimplementasikan secara tajam dalam bentuk kurikulum dalam rencana belajar dan masa belajar. ${ }^{38}$ Sebenarnya sampai saat ini belum ada rumusan kurikulum baku yang dipakai oleh semua pesantren (seperti kurikulum baku yang ada di pendidikan formal). Bila bicara kurikulum pesantren, maka yang terjadi dan dilaksanakan di pesantren mulai dari pagi hingga malam itulah kurikulum pesantren. Hal ini sesuai dengan pengertian kurikulum, bahwa kurikulum adalah sejumlah pengalaman bagi peserta didik.

Kurikulum di pesantren adalah kehidupan yang ada di pesantren itu sendiri. Dalam ungkapan lain, dua puluh jam kehidupan santri sehari merupakan proses dan representasi pendidikan. Pendidikan pesantren tidak selesai dengan usainya pengajian kitab. Ketika para santri istirahat, kemudian makan, sholat, tidur, dan bangun tengah malam; semua aktivitas ini adalah bagian intrinsik dari pendidikan. ${ }^{39}$ Maka dari itu, ketika para santri melakukan kegiatan mereka, kiai pengasuh mengawasi secara teliti kesesuaian kegiatan santri dengan materi pelajaran yang telah mereka peroleh.

\section{Tahap Pelaksanaan}

Tahap pelaksanaan merupakan implementasi dari perencanaan. Adapun ruang lingkup pada tahap pelaksanaan ini adalah sebagai berikut:

\footnotetext{
${ }^{38}$ Saifudin Zuhri, "Reformulasi Kurikulum Pesantren," Ismail SM, dkk., Dinamika Pesantren dan Madrasah (Yogyakarta: Pustaka Pelajar, 2002), 98.

${ }^{39}$ Nafi', dkk., Praksis Pembelajaran, 86.
} 


\section{a. Pengorganisasian Santri}

Santri menjadi komponen utama dalam pencapaian tujuan utama pendidikan life skills lembaga pendidikan pesantren. Hendaknya dapat diorganisir sedemikian rupa agar terjadi kegiatan pembelajaran yang partisipatif dan peserta didik (santri) memperoleh hal-hal yang pragmatis. Siswa (santri) dalam suatu kelas biasanya memiliki kemampuan yang beragam: pandai, sedang, dan kurang. Karenanya guru harus mengatur kapan siswa itu bekerja perorangan, berpasangan, berkelompok atau klasikal.

\section{b. Pengelolaan Kelas}

Keberhasilan guru melaksanakan kegiatan pembelajaran tidak saja menuntut kemampuan menguasai materi pelajaran, strategi, dan metode mengajar, menggunakan media atau alat pembelajaran. Tetapi, guru melakukan tugas profesionalnya dituntut untuk memiliki kemampuan yang lain, yaitu menyediakan atau menciptakan situasi dan kondisi belajar yang kondusif dan menyenangkan. Kondisi kelas yang kondusif dan menyenangkan dapat terwujud jika guru mampu mengatur suasana pembelajaran, mengkondisikan siswa untuk belajar dan memanfaatkan atau menggunakan sarana pengajaran serta dapat mengendalikannya dalam suasana yang menyenangkan untuk mencapai tujuan pembelajaran.

\section{c. Metode Pembelajaran}

Metode pembelajaran adalah cara-cara yang mesti ditempuh dalam kegiatan belajar mengajar antara santri dan kiai untuk mencapai suatu tujuan tertentu. Secara metodik, pendidikan dan pengajaran dalam pesantren diberikan dalam bentuk sorogan, bandongan, halaqah dan hafalan. Metode mengajar sorogan dan bandongan menjadi ciri khas pesantren dan sebagaian para pakar pendidikan menganggap metode tersebut merupakan metode yang statis dan tradisional. Namun, bukan berarti tanpa inovasi. Metode sorogan justru mengutamakan kema- 
tangan, perhatian, dan kecakapan seseorang. ${ }^{40}$ Metode yang diterapkan pesantren pada prinsipnya mengikuti selera kiai, yang dituangkan dalam kebijakan-kebijakan pendidikannya. Dari perspektif metodik, pesantren terpolarisasikan menjadi tiga kelompok: a) kelompok pesantren yang hanya menggunakan metode yang bersifat tradisional dalam pengajaran kitab-kitab Islam klasik, b) kelompok pesantren yang hanya menggunakan metode-metode hasil penyesuaian dengan metode yang dikembangkan pendidikan formal, dan c) kelompok pesantren yang menggunakan metode-metode yang bersifat tradisional dan mengadakan penyesuaian dengan metode pendidikan yang dipakai dalam pendidikan formal. ${ }^{41}$

\section{d. Sarana, Prasarana, dan Fasilitas Belajar}

Pendidikan life skills membutuhkan sarana prasarana yang representatif untuk menggugah semangat anak didik (santri) dalam menggali dan mengembangkan potensinya. Diperlukan peralatan yang disesuaikan dengan spesifikasi skills yang diharapkan. ${ }^{42}$ Hal yang harus menjadi catatan ialah jangan sampai peralatan dan perlengkapan yang diperlukan itu tidak tersedia ketika proses pembelajaran dilaksanakan. ${ }^{43}$ Sarana prasarana di pesantren merupakan bagian dari unsur pesantren. Sarana tersebut dapat dibagi menjadi dua, sarana perangkat keras, meliputi masjid, rumah kiai, rumah, dan asrama ustaz, pondok atau asrama santri, sarana, dan prasarana fisik lainnya. Sarana kedua adalah sarana perangkat lunak, meliputi tujuan, kurikulum, kitab penilaian, tata tertib, cara pengajaran, perpustakaan, pusat dokumentasi, dan penerangan, keterampilan, dan alat-alat pendidikan lainnya. ${ }^{44}$

\footnotetext{
${ }^{40}$ Muthohar, Ideologi Pendidikan Pesantren, 27-28.

${ }^{41}$ Qamar, Pesantren, 150.

${ }^{42}$ Asmani, Sekolah Life Skill, 153-154.

${ }^{43}$ Suherman, Desain Pembelajaran, 56.

${ }^{44}$ Muthohar, Ideologi Pendidikan Pesantren, 18.
} 


\section{Tahap Evaluasi}

Komponen terakhir dari desain pendidikan life skills adalah sistem evaluasi. Evaluasi adalah cara penilaian yang dilakukan oleh seorang ustaz untuk mengetahui kemampuan santri dalam aspek pengetahuan (kognisi) aspek sikap (afeksi) dan aspek keterampilan (skill) terhadap materi pembelajaran yang telah diberikannya. ${ }^{45}$ Penilaian dilakukan di samping berguna untuk mengetahui tingkat perkembangan kemampuan penguasaan santri juga berfungsi sebagai umpan balik (feedback) bagi seorang kiai atau ustaz untuk meninjau kembali cara-cara yang dilakukannya berkenaan dengan penggunaan suatu metode pemebelajaran tertentu. Karena keberhasilan pembelajaran kepada para santri amat ditentukan oleh kemampuan belajar santri dan kemampuan membimbing ustaz.

Akan tetapi, di pesantren sistem evaluasi kurang mendapat perhatian. Di pesantren-pesantren Salaf evaluasi atau tes sering kali diabaikan. Santri memperoleh pengetahuan dari guru hingga menamatkan kitab yang diajarkan kemudian beralih ke kitab lain yang lebih tinggi tanpa mengevaluasi hasil pembelajaran dari kitab sebelumnya. Hal ini dapat dimaklumi mengingat di awal pembelajaran, tujuan pengajaran tidak dijelaskan sehingga sangat sulit untuk mengevaluasi hasil yang telah dicapai. ${ }^{46}$ Dalam hal evaluasi, keberhasilan belajar di pesantren ditentukan oleh penampilan mengajar kitab kepada orang lain. Artinya, jika audiens puas, berarti santri tersebut telah lulus sehingga legitimasi kelulusannya adalah restu kiai. Bentuk sistem evaluasi lainnya adalah selesainya pengajian suatu kitab di pesantren dalam waktu tertentu, lalu diberikan ijazah yang bentuknya adalah santri harus siap membaca kitab sewaktuwaktu kiai memanggilnya untuk membaca kitab tersebut. Dalam hal ini biasanya santri yang cerdas yang akan dimintai kiai sebagai penggantinya (badal). Selain dua bentuk evaluasi di atas, sistem evaluasi pesantren

\footnotetext{
${ }^{45}$ Direktorat Jendral Kelembagaan Agama Islam, Pola Pembelajaran, 82.

46 M. Syairozi Dimyathi, "Mencermati Kurikulum Tafsir di Pesantren dan Madrasah Tsanawiyah di Indonesia." www.psq.or.id/index.php/in/component/content/article/102artikel/211-mencermatikurikulum-tafsir-di-pesantren-dan-madrasah-tsanawiyah-diindonesia. Diakses pada 26 April 2011.
} 
lebih ditentukan pada kemampuan santri dalam mentransformasikan nilai ajaran agama melalui ilmu dari pesantren di masyarakat. Hal ini akan memungkinkan adanya evaluasi diri (self-evaluation) sehingga memungkinkan penilaian objektif dengan cara santri mengukur sendiri prestasi belajar. ${ }^{47}$ Dari gambaran di atas, dapat diketahui bahwa sistem evaluasi di pesantren belum dilakukan secara formal.

\section{Penutup}

Pondok Pesantren Darul Falah Be-Songo Ngaliyan Semarang telah menyelenggarakan kegiatan-kegiatan yang berwawasan kecakapan hidup (life skills). Dikatakan demikian karena di dalam pesantren tersebut tidak hanya diajarkan ilmu-ilmu agama semata, banyak cakupan life skills yang ditawarkan kepada santri, tidak hanya kecakapan secara umum akan tetapi kecakapan secara spesifik. Kecakapan tersebut meliputi kecakapan vokasional dan kecakapan akademik. Kecakapan vokasional di sini berupa skills memasak, menyulam, merias, dan jenis kerajinan yang lain. Selain itu, di dalamnya juga diajarkan bagaimana para santri dapat berbicara dengan baik, baik dalam mengemukakan pendapat maupun dalam berpidato dan skill-skill yang lain yang menjadi daya tarik sendiri bagi masyarakat sekitar.

Pendidikan life skills dapat diartikan sebagai pendidikan yang memberikan bekal dasar dan latihan yang dilakukan secara benar kepada peserta didik tentang nilai-nilai kehidupan yang dibutuhkan dan berguna bagi perkembangan kehidupan peserta didik. Dengan demikian, pendidikan life skills harus dapat merefleksikan kehidupan nyata dalam proses pengajaran agar peserta didik memperoleh kecakapan hidup di tengahtengah masyarakan. Manfaatnya dapat meningkatkan kualitas berpikir, kualitas kalbu, dan kualitas fisik santri. Selain itu, bagi lingkungan di mana santri itu berada atau bagi masyarakat dapat meningkatkan kehidupan yang maju dan madani. Adapun pelaksanaan pendidikan life skills di pesantren, utamanya ini Pondok Pesantren Darul Falah Be-

\footnotetext{
${ }^{47}$ Muthohar, Ideologi Pendidikan Pesantren, 29-30.
} 
Songo Ngaliyan Semarang terdapat tiga tahap, yaitu tahap perencanaan, tahap pelaksanaan, dan tahap evaluasi yang semuanya dilakukan bertujuan agar pendidikan ini sesuai dengan saran yang dibuat.

\section{Daitar Pustaka}

Arikunto, Suharsimi. Prosedur Penelitian Suatu Pendekatan Praktik. Jakarta: Rineka Cipta, 2010.

Asmani, Jamal Ma’mur. Sekolah Life Skills Lulus Siap Kerja! Yogyakarta: Diva Press, 2009.

Departemen Agama Direktorat Jenderal Kelembagaan Agama Islam. Pedoman Integrasi Pendidikan Kecakapan Hidup (Life Skills) dalam Pembelajaran Madrasah Ibtidaiyah dan Madrasah Tsanawiyah. Jakarta: Departemen Agama Direktorat Jenderal Kelembagaan Agama Islam, 2005.

Dimyathi, M. Syairozi. "Mencermati Kurikulum Tafsir di Pesantren dan Madrasah Tsanawiyah di Indonesia." www.psq.or.id/index.php/ in/component/content/article/102-artikel/211-mencermati-kurikulum-tafsirdi-pesantren-dan madrasah-tsanawiyah-di-indonesia. Diakses pada Kamis, 26 April 2011.

Efendi AR, Moch. "Implementasi Pendidikan Kecakapan Hidup di Pesantren Pondok: Studi Kasus Pesantren Kiai Ageng Selo Klaten.” Skripsi. IAIN Walisongo Semarang, 2009.

Gazali, Bahri. Pendidikan Pesantren Berwawasan. Jakarta: Pedoman Ilmu Jaya, 2001.

Hadi, Sutrisno. Metodologi Research. Yogyakarta: Andi Offset, 1989.

Haedari, Amin. Masa Depan Pesantren dalam Tantangan Modernitas dan Tantangan Kompleksitas Global. Jakarta: IRD Press, 2004.

Hamalik, Oemar. Kurikulum dan Pembelajaran. Jakarta: Bumi Aksara, 2011 
Hajar, Ibnu. Kiai di Tengah Pusaran Politik. Jakarta: IRCiSoD, 2009

Khasanah, Fitriyatun. "Upaya Pesantren Berbasis Agribisnis dalam Meningkatkan Life Skill Santri Pondok Pesantren: Studi Kasus di Pondok Pesantren al-Ishlah, Desa Serangsari, Kecamatan Kejajar, Kabupaten Wonosobo." Skripsi. IAIN Walisongo Semarang.

Minan, M. Wahabul. "Urgensi Pendidikan Pesantren dalam Pembentukan Kepribadian Muslim." Skripsi. IAIN Walisongo Semarang, 2007.

Misbahul, Munir. “Tolong Menolong dalam Kehidupan Santri: Studi Kasus di Pondok Pesantren Darun Najah Tugu Semarang." Skripsi. IAIN Walisongo Semarang.

Muthohar, Ahmad. Ideologi Pendidikan Pesantren: Pesantren di Tengah Arus Ideologi-Ideologi Pendidikan. Semarang: Pustaka Rizki Putra, 2007.

Muhtarom. "Urgensi Pesantren dalam Pembentukan Kepribadian Muslim.” Ismail SM, et.al. Dinamika Pesantren dan Madrasah. Yogyakarta: Pustaka Pelajar \& Fakultas Tarbiyah IAIN Walisongo Semarang, 2002.

Muhadjir, Noeng. Metodologi Penelitian Kualitatif Pendekatan Positiftik, Rasionalistik, Phenomenologik, dan Realisme Metaphisik: Telaah Studi Teks dan Penelitian Agama. Yogyakarta: PT. Bayu Indra Grafika, 1969.

Moleong, Lexy J. Metodologi Penelitian Kualitatif(Edisi Revisi). Bandung: PT. Remaja, 2007.

Masyhud, M. Sulthon \& Moh. Khusnurdilo. Manajemen Pondok Pesantren. Jakarta: Diva Pustaka, 2004.

Mohan, Hanafi. http://hanafimohan.blogspot.com/2009/05/cerbungsenja-merah-jingga-16-seni.html, diakses pada 05 Maret 2012.

Nafi, Dian, et.al. Praksis Pembelajaran Pesantren. Yogyakarta: LKiS, 2007. Nizar, Samsul. Sejarah Pendidikan Islam: Menelusuri Jejak Sejarah Pen- 
didikan Era Rasulullah Sampai Indonesia. Jakarta: Kencana, 2007.

Nata, Abuddin. Sejarah Pertumbuhan dan Perkembangan Lembaga-Lembaga Pendidikan Islam di Indonesia. Jakarta: PT Grafindo, 2001.

Qomar, Mujamil. Pesantren dari Transformasi Metodologi Menuju Demokratisasi Institusi. Jakarta: PT. Gelora Aksara Pratama, 2007.

S. Margono. Metodologi Penelitian Pendidikan. Jakarta: Rineka Cipta, 2010.

Sugiyono. Metode Penelitian Kuantitatif, Kualitatif, dan R\&D. Bandung: CV. Alfabeta, 2009. . Metode Penelitian Pendidikan: Pendekatan Kuantitatif, Kualitatif, dan R\&D. Bandung: Alfabeta, 2007.

Subagyo, Joko. Metode Penelitian: Dalam Teori dan Praktik. Jakarta: PT. Rineka Cipta, 2004.

Sukardi. Metodologi Penelitian Pendidikan: Kompetensi dan Praktiknya. Jakarta: Bumi Aksara, 2009.

Suranto, "Konsep Kecakapan Hidup (Life Skills) dan Implikasinya dalam Pendidikan Islam.” Skripsi. UIN Sunan Kalijaga Yogyakarta, 2009.

Taufiq, Imam. “Understanding Conflict.” Makalah. Disampaikan pada acara Pelatihan Peningkatan Kapasitas Pesantren dan Resolusi Konflik di Indonesia, pada 13 Februari 2012.

Tim Direktorat Jenderal Kelembagaan Agama Islam bekerja sama dengan direktorat Pendidikan Keagamaan dan Pondok Pesantren dan Proyek Peningkatan Pendidikan Luar Sekolah pada Pondok Pesantren. Pola Pembelajaran di Pesantren. Jakarta: Direktorat Jendral Kelembagaan Agama Islam, 2003.

Tim Broad Based Education Depdiknas. Kecakapan Hidup Melalui Pendekatan Pendidikan Berbasis Luas. Surabaya: Surabaya Intellectual Club (SIC) \& Lembaga Pengabdian Masyarakat Universitas Negeri Surabaya (Unesa), 2002. 